\title{
LETTERS
}

\section{Flawed arguments in this commentary}

I am writing in response to Mr. Matthew Herder and Dr. David Juurlink's proposal for ministerial recall of high-dose opioid formulations. ${ }^{1}$

With respect, there are many serious flaws in this commentary. To begin with, Health Canada has always had the ability to issue warnings about drugs and to recall drugs. The fact that Health Canada has not done this with higher doses of opioids is likely because there is no reason to do so. Vanessa's Law came into force in 2014, but it was 2000 when the teenager whose death inspired the law unfortunately passed away from a reaction to cisapride. That same year, Health Canada requested that it be removed from the market, and it was.

In response to my question, Health Canada stated that it has never had to invoke this legislation (www.painnews network.org/stories/2018/12/3/prop-in -canada).

Ontario removed high doses of opioids from the drug formulary a few years ago. The higher doses are no longer covered for patients receiving social assistance or for older patients. As a result, doctors now prescribe lower doses in combination to make up for that. Now, instead of a $100 \mu \mathrm{g}$ patch of fentanyl, patients are prescribed two $50-\mu \mathrm{g}$ patches. How is this safer?

The real problem with overdose deaths in this country is illicit fentanyl. The BC Coroners Service is the only coroners service in Canada that rules on the source of opioids in overdose deaths, and it finds consistently that it is illicit fentanyl and not pre- scribed opioids. ${ }^{2,3}$ Further, as Global News reported, ${ }^{4}$ one Chinese criminal enterprise is responsible for millions of dollars in smuggled drugs into Canada, and the police have few resources to fight this. And don't forget about the Ontario pharmacists caught distributing millions of dollars more of opioids into the black market. ${ }^{5}$

It is time to focus on these criminals, and not on patients with pain and the doctors who are trying to help them.

\section{Marvin Ross MA}

Medical writer, Bridgeross

Communications, Dundas, Ont.

Cite as: CMAJ 2019 March 18;191:E318. doi: $10.1503 / \mathrm{cmaj} .71557$

\section{References}

1. Herder M, Juurlink D. High-strength opioid formulations: the case for a ministerial recall. CMAJ 2018;190:E1404-5.

2. $B C$ Coroners Service releases expanded findings into overdose deaths. BC Gov News 2018 Sept. 27. Available: https://news.gov.bc.ca/releases/ 2018PSSG0072-001880 (accessed 2018 Dec. 4).

3. Gomes T, Greaves S, Martins D, et al. Latest trends in opioid-related deaths in Ontario: 1991 to 2015. Toronto: Ontario Drug Policy Research Network; 2017. Available: http://odprn.ca/wp -content/uploads/2017/04/ODPRN-Report_Latest -trends-in-opioid-related-deaths.pdf (accessed 2018 Dec. 4).

4. Cooper S, Bell S, Russell A. Fentanyl kings in Canada allegedly linked to powerful Chinese gang, the Big Circle Boys. Global News 2018 Nov. 27. Available: https://globalnews.ca/news/4658158/ fentanyl-kingpins-canada-big-circle-boys (accessed 2018 Dec. 4).

5. Chown Oved M, Cribb R, Jarvis C, et al. Drugdealing pharmacists are feeding Ontario's opioid crisis. The Star 2018 Sept. 24. Available: www.the star.com/news/investigations/2018/09/24/drug -dealing-pharmacists-feed-opioid-crisis.html (accessed 2018 Dec. 4).

Competing interests: None declared. 